\title{
Culicoides species abundance and potential over- wintering of African horse sickness virus in the Onderstepoort area, Gauteng, South Africa
}

\begin{abstract}
Authors:
Gert J. Venter ${ }^{1,2}$

Karien Labuschagne $\mathrm{e}^{1,3}$ Daphney Majatladi ${ }^{1}$

Solomon N.B. Boikanyo ${ }^{1}$ Carina Lourens ${ }^{4}$

Karen Ebersohn ${ }^{2}$

Estelle H. Venter ${ }^{2}$

\section{Affiliations:}

${ }^{1}$ Parasites, Vectors and Vector-borne Diseases Programme, Agricultural Research Council Onderstepoort Veterinary Institute, South Africa

${ }^{2}$ Department of Veterinary Tropical Diseases, University of Pretoria, South Africa

${ }^{3}$ Department of Zoology and Entomology, University of Pretoria, South Africa
\end{abstract}

${ }^{4}$ Equine Research Centre, University of Pretoria, South Africa

\section{Correspondence to:}

Gert Venter

Email:

venterg@arc.agric.za

\section{Postal address:}

Private Bag X05,

Onderstepoort 0110,

South Africa

\section{Dates:}

Received: 01 Sept. 2013

Accepted: 07 Feb. 2014

Published: 14 Nov. 2014

Read online:

Scan this QR code with your smart phone or mobile device to read online.
In South Africa, outbreaks of African horse sickness (AHS) occur in summer; no cases are reported in winter, from July to September. The AHS virus (AHSV) is transmitted almost exclusively by Culicoides midges (Diptera: Ceratopogonidae), of which Culicoides imicola is considered to be the most important vector. The over-wintering mechanism of AHSV is unknown. In this study, more than 500000 Culicoides midges belonging to at least 26 species were collected in 88 light traps at weekly intervals between July 2010 and September 2011 near horses in the Onderstepoort area of South Africa. The dominant species was C. imicola. Despite relatively low temperatures and frost, at least 17 species, including $C$. imicola, were collected throughout winter (June-August). Although the mean number of midges per night fell from $>50000$ (March) to < 100 (July and August), no midge-free periods were found. This study, using virus isolation on cell cultures and a reverse transcriptase polymerase chain reaction (RT-PCR) assay, confirmed low infection prevalence in field midges and that the detection of virus correlated to high numbers. Although no virus was detected during this winter period, continuous adult activity indicated that transmission can potentially occur. The absence of AHSV in the midges during winter can be ascribed to the relatively low numbers collected coupled to low infection prevalence, low virus replication rates and low virus titres in the potentially infected midges. Cases of AHS in susceptible animals are likely to start as soon as Culicoides populations reach a critical level.

\section{Introduction}

African horse sickness (AHS), an arthropod-borne viral disease affecting all equines, is considered to be the most lethal viral disease of horses. The agent, AHS virus (AHSV), a double-stranded ribonucleic acid (RNA) virus in the genus Orbivirus (Reoviridae), is enzootic in sub-Saharan Africa. Outbreaks can occur, however, well beyond this region (Coetzer \& Guthrie 2004; MacLachlan \& Guthrie 2010). All nine serotypes (Howell 1962; McIntosh 1958) are transmitted almost exclusively by certain species of blood feeding flies, $1 \mathrm{~mm}-3 \mathrm{~mm}$ in size, of the genus Culicoides (Diptera: Ceratopogonidae) (Wilson et al. 2009). The geographic distribution and seasonal incidence of AHSV depend not only on the presence of the virus and susceptible equines but also on the presence and abundance of competent vectors (Mellor, Boorman \& Baylis 2000). As a result of its host preference for larger mammals, wide geographic distribution, abundance in light trap collections and isolation of AHSV and other viruses from field-collected specimens, Culicoides imicola is considered to be the principal vector of orbiviruses of livestock in southern Africa (Meiswinkel, Venter \& Nevill 2004; Nevill, Venter \& Edwardes 1992).

In South Africa, AHS is endemic in the frost-free north-eastern parts of the country, where it is maintained in zebra (Equus burchelli) populations that foal throughout the year (Barnard 1993). Although the first cases of AHSV for a particular season are recently often reported from Gauteng, Kwazulu-Natal or even the Eastern Cape (AHS Trust 2012), it is still generally accepted that seasonal epidemics spread from the Kruger National Park and adjacent parks moving south and westwards (Coetzer \& Guthrie 2004). The extent of these annual AHS epidemics is dependent on favourable climatic conditions that will increase breeding and spread of the vector (Coetzer \& Guthrie 2004). Epidemiological data from 1955 to 1995 showed that outbreaks occurred nearly every summer in the subtropical northern parts of South Africa, once every 5-10 years in the cooler centre of the country, and only rarely in the Western Cape in the south (Bosman, Brückner \& Faul 1995). Outbreaks are usually associated with large C. imicola populations (Venter, Koekemoer \& Paweska 2006), with a peak in the latter half of summer and no cases reported between July and

How to cite this article: Venter, G.J., Labuschagne, K., Majatladi, D., Boikanyo, S.N.B., Lourens, C., Ebersohn, K. et al., 2014, 'Culicoides species abundance and potential over-wintering of African horse sickness virus in the Onderstepoort area, Gauteng, South Africa', Journal of the South African Veterinary Association 85(1), Art. \#1102, 6 pages. http://dx.doi.org/10.4102/jsava.v85i1.1102

Copyright: @ 2014. The Authors. Licensee: AOSIS OpenJournals. This work is licensed under the Creative Commons Attribution License. 
September. Despite the interruptions in normal transmission, AHSV is able to persist for long periods during adverse conditions without new cases. These absences of up to eleven and a half months can create the deceptive impression that an outbreak has ended (Wilson et al. 2009).

Based on diagnostic results, outbreaks of AHS have increased over the last decade and tend to occur earlier than usual in most parts of South Africa. For example, during 2012/2013 cases of AHS were detected in Gauteng in November 2012, at least 2 months before cases were reported from the more northerly areas of South Africa (AHS Trust 2012).

The objective of this study was to monitor the seasonal abundance of Culicoides midges in the Onderstepoort area, Gauteng, South Africa and to determine if AHSV can potentially over-winter in adult populations. The presence of adult midges and over-wintering of AHSV will imply that the virus circulates all year long in the area and does not need to be introduced annually from more subtropical regions.

\section{Materials and methods Collection site}

The Agricultural Research Council - Onderstepoort Veterinary Institute (ARC-OVI) (2539'S, 28 $11^{\circ} \mathrm{E}, 1219$ m.a.s.1.) is situated in the Gauteng province of South Africa. There is a mean of 32.8 days when the minimum temperature is below freezing point, and a further 70.8 days when it is below $5{ }^{\circ} \mathrm{C}$. It is a summer rainfall area with an annual mean rainfall of $706 \mathrm{~mm}$ (Venter et al. 1996). The predominantly black cotton soils, characteristic of the Onderstepoort area, are an ideal breeding habitat for C. imicola (Meiswinkel et al. 2004).

A single light trap was placed underneath the eaves of a stable housing between 20 and 30 horses at night. The stable was surrounded by open camps, characterised by some trees and patches of grass, where an additional 10-15 horses were kept. There were other horses in open camps $100 \mathrm{~m}-200 \mathrm{~m}$ away. Daily maximum and minimum outside temperatures at the light trap were recorded using a Tinytag Explorer (Gemini Data Loggers UK Ltd.).

\section{Insect collection}

An 8-watt 220-volt down-draught Onderstepoort black light trap was used to collect adult Culicoides midges (Venter et al. 2009). Trapping was conducted one night a week from July 2010 to September 2011. Frequency of collection was increased (up to 5 nights per week) during the colder winter months (July and August 2011) (Table 1).

Culicoides midges were collected in phosphate buffered saline (PBS) to which $0.5 \%$ Savlon $^{\circledR}$ antiseptic (Johnson \& Johnson, South Africa), containing chlorhexidine gluconate $0.3 \mathrm{~g} / 100 \mathrm{~mL}$ and cetrimide $3.0 \mathrm{~g} / 100 \mathrm{~mL}$, had been added (Walker \& Boreham 1976). Collections were retrieved the following morning and the insects washed with PBS and stored in PBS at
$4{ }^{\circ} \mathrm{C}$ until analysed. Large collections were subsampled (Van Ark \& Meiswinkel 1992). Based on abdominal pigmentation (Dyce 1969), the females of all species were age-graded into unpigmented (nulliparous), pigmented (parous), gravid or freshly blood-fed. Males were also counted. After the Culicoides midges were analysed down to species level and age-graded, they were removed from the PBS and stored in $1.5 \mathrm{~mL}$ vials at $-80^{\circ} \mathrm{C}$ until assayed for the presence of AHSV.

\section{Virus detection}

Virus detection was done on the weekly Culicoides collections using baby hamster kidney cell cultures (BHK-21) as well as by molecular methods. Virus isolation from pools of fieldcollected midges was done as described previously (Venter et al. 2006). Insects were homogenised (Precellys Lysing Kit CK 14, Anatech, South Africa) and tested for the presence of AHSV RNA by reverse transcriptase polymerase chain reaction (RTPCR) according to a published protocol (Quan et al. 2010).

\section{Ethical considerations}

Materials used in the experiment posed no health risk to researchers and no vertebrate animals were harmed. The project was approved and financially supported by the Gauteng Department of Agriculture and Rural Development (project number: OV07/23/C231).

\section{Results}

Midges were collected weekly for 15 months (from end of July 2010 to beginning of September 2011) and more than 500000 were collected in 88 collections (Table 1 ). The monthly mean per night ranged from 67.0 in July 2010 to 52434.6 in March 2011 and the overall mean for the period was 5747.8 midges per night (Table 1). Relatively high numbers were found throughout winter (Figure 1; Table 1). Although Culicoides midges were absent from the traps on 04-06 July and 26-27 July 2011, the mean for 20 collections in July was 71.3 midges per night (Table 1). The maximum collected in a single night during July was 240.

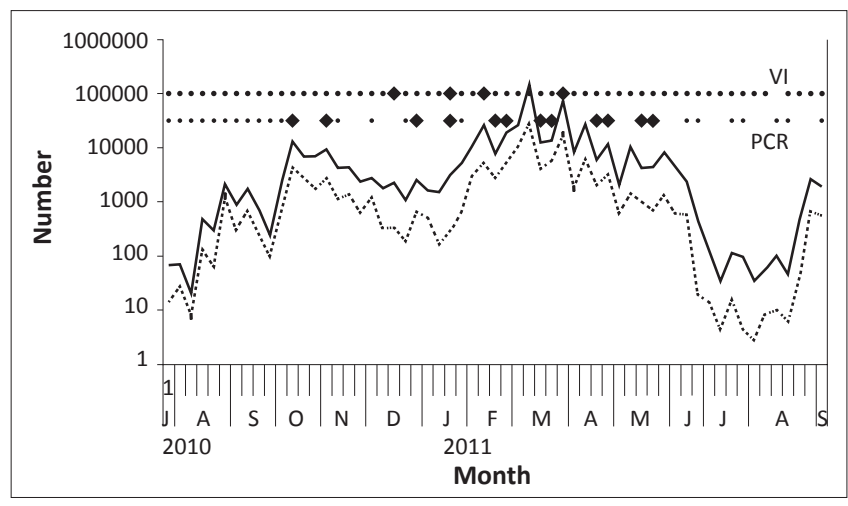

Note: Dots indicate which samples were used for virus isolation (VI) using BHK-21 cells and reverse transcriptase polymerase chain reaction (RT-PCR) respectively. Black diamond shapes indicate samples in which virus could be detected.

FIGURE 1: Mean number of Culicoides midges (solid line) and mean number of parous females (broken line) collected per week with a light trap near horses at the Agricultural Research Council - Onderstepoort Veterinary Institute (from last week of July 2010 to first week of September 2011). 
The minimum monthly temperature recorded at the trap ranged from $-3.7^{\circ} \mathrm{C}$ in June to $13.5^{\circ} \mathrm{C}$ in December (Figure 2). The maximum monthly temperature recorded ranged from $25.8^{\circ} \mathrm{C}$ in June to $42.0^{\circ} \mathrm{C}$ in December (Figure 2). In June and July 2011, there were at least 17 nights when the minimum temperature dropped to below $0{ }^{\circ} \mathrm{C}\left(-4.5^{\circ} \mathrm{C}\right)$.

Culicoides midges belonging to 26 different species were collected (Table 1). Culicoides imicola was dominant throughout the period (Table 1). The mean numbers of C. imicola collected per night ranged from 58.5 in July 2011 to 48650.4 in March 2011 (Table 1). Its representation ranged from $74.9 \%$ in January 2011 to $96.2 \%$ in August 2010 whilst its mean representation was $90.8 \%$ (Table 1 ). The second most abundant species, Culicoides enderleini, accounted for $2.3 \%$ of the total number (Table 1 ) and its highest mean number (1598.6) was collected in March 2011 (Table 1). This species was absent from the collections made in July (Table 1). Culicoides nevilli, at $1.4 \%$, was the third most abundant (Table 1). In the table, where Culicoides species numbers appear instead of a species name, the numbering system of Meiswinkel (1995) was followed to refer to as yet undescribed species.

Parous females (females that have had at least one blood meal and completed one gonotrophic cycle and therefore potentially infected with AHSV) were present throughout the year (Figure 1). Their mean number ranged from 13361.4 collected in March 2011 to 7.2 in July 2011. On average, parous females represented $24.6 \%$ of the total. The representation of parous females was consistently lower than the average during winter (from May to July) (Figure 1).Taking into account only the numbers of parous females, C. imicola $(94.9 \%)$ was still the most abundant and at $2.2 \%$ C. enderleini remained the second most dominant species. In the parous grouping, however, Culicoides bolitinos $(0.8 \%)$ replaced C. nevilli $(0.5 \%)$ as the third most abundant species. Freshly blood-fed females and males were collected throughout both winter seasons (from June to August).

During December and January, Culicoides midges belonging to at least 23 species were collected (Table 1) whilst during

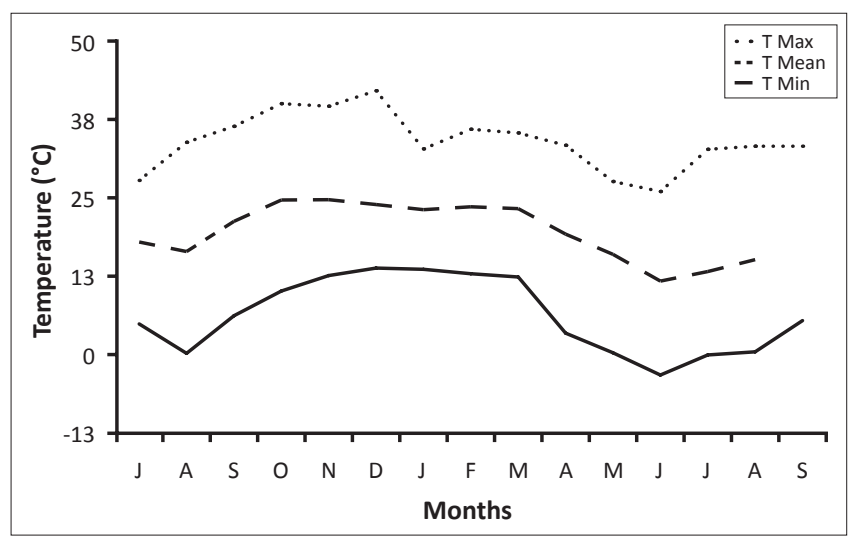

T, temperature; Min, minimum; Max, maximum.

FIGURE 2: The monthly minimum, maximum and mean temperature recorded at a light trap used for the collection of Culicoides midges at the Agricultural Research Council - Onderstepoort Veterinary Institute (July 2010 - September 2011).
June and July 2011 the number of species present dropped to 10 (Table 1). Despite the lower species richness, midges belonging to at least 17 species were present throughout winter (from June to August) (Table 1). Even if only parous females are taken into account, a minimum of 13 species remained throughout winter.

\section{Virus detection}

Virus isolation, using cell culture, was attempted on all 60 weekly pools (Figure 1). After three passages on BHK21 cells, viable virus was only recovered from four pools. These viruses were not typed or further identified. These midges were collected in summer during the nights of 08-09 December 2010 (pool size $n=1770), 10-11$ January $2011(n$ $=1514), 01-02$ February $2011(n=10$ 728) and 22-23 March 2011 ( $n=13519)$. These positive isolations correlate well with relatively high numbers of midges (> 1000) (Figure 1) and the seasonal occurrence of AHSV in the Onderstepoort area.

Representative samples covering the 15-month collection period were subjected to RT-PCR. Viral nucleic acid was detected in 12 of 35 pools assayed (Figure 1) with cycle threshold (CT) values ranging between 26.20 and 39.02. The first RT-PCR positive pools were found early in October 2010 (Figure 1). Virus was detected in one of three pools assayed in November and all 11 pools tested between December 2010 and May 2011, except for one pool in January, were positive (Figure 1). No positive pools were found after 24 May and this related to a drop in the mean catch size and proportion of parous individuals (Figure 1). As no viral nucleic acid was detected in any pool of $<3500$ midges, positive RT-PCR results, as for virus isolation, seemed to correlate with high numbers of midges (Figure 1).

\section{Discussion}

Despite the fact that there were nights when the minimum temperature at the collection site was well below freezing point $\left(-4.5^{\circ} \mathrm{C}\right)$ with frost occurring, nulliparous, parous, freshly blood-fed and gravid females as well as males were present throughout the sampling period. Culicoides imicola, considered a proven vector of AHSV, was found throughout the year and no midge-free periods were recorded. Although the mean number collected per night dropped from > 50000 in March to $<100$ in July and August, midges were present each week. The maximum number of $C$. imicola collected in July was 189 individuals, of which 188 were females, including 23 parous ones. The presence of males indicates that breeding continued throughout winter. The presence of freshly blood-fed females of most species, including C. imicola, in winter implies that blood feeding and the transmission of AHSV can potentially continue throughout winter. The results of this study, done near horses, is supported by previous work conducted near livestock at Onderstepoort (Nevill 1971; Venter, Nevill \& Van der Linde 1997) and also near a variety of caged wild animals at the nearby National Zoological Gardens of South Africa in Pretoria (Labuschagne 2007). These studies also showed that adult midges could be present throughout winter. 
TABLE 1: Identification and mean number of the Culicoides species recovered from 88 black light trap collections near horses at the Agricultural Research Council Onderstepoort Veterinary Institute (July 2010 - September 2011).

\begin{tabular}{|c|c|c|c|c|c|c|c|c|c|c|c|c|c|c|c|c|c|}
\hline \multirow[t]{2}{*}{ Species } & \multicolumn{6}{|c|}{2010} & \multicolumn{9}{|c|}{2011} & \multirow[t]{2}{*}{ Total } & \multirow[t]{2}{*}{$\%$} \\
\hline & July & Aug. & Sept. & Oct. & Nov. & Dec. & Jan. & Feb. & Mar. & Apr. & May & June & July & Aug. & Sept. & & \\
\hline Number of collections & 1 & 5 & 4 & 4 & 5 & 6 & 4 & 4 & 5 & 4 & 5 & 6 & 20 & 14 & 1 & 88 & - \\
\hline C. imicola & 63.0 & 593.0 & 820.8 & 5820.5 & 3352.8 & 1546.2 & 2110.3 & 14609.5 & 48650.4 & 13053.5 & 5585.4 & 1142.5 & 58.5 & 270.3 & 1658.0 & 459372 & 90.8 \\
\hline C. enderleini & - & 1.0 & 0.3 & 42.0 & 17.4 & 18.0 & 72.0 & 502.0 & 1598.6 & 190.8 & 9.8 & 2.0 & - & 1.6 & 2.0 & 11506 & 2.3 \\
\hline C. nevilli & - & 3.0 & 5.3 & 46.8 & 21.8 & 8.3 & 17.3 & 22.0 & 1156.0 & 70.0 & 23.6 & 4.5 & 0.5 & 9.4 & 67.0 & 6951 & 1.4 \\
\hline C. nivosus & - & 2.0 & 13.5 & 172.5 & 304.8 & 180.2 & 239.3 & 299.0 & 112.6 & 27.0 & 18.4 & - & 0.1 & 0.6 & 1.0 & 6285 & 1.2 \\
\hline C. pycnostictus & 2.0 & 4.6 & 12.0 & 369.5 & 187.2 & 71.2 & 165.0 & 264.5 & 147.6 & 44.5 & 14.2 & 2.7 & 0.1 & 0.4 & 3.0 & 5644 & 1.1 \\
\hline C. bolitinos & - & 3.0 & 2.3 & 13.8 & 10.8 & 5.5 & 17.0 & 101.0 & 419.6 & 85.3 & 248.6 & 64.7 & 9.9 & 5.6 & 14.0 & 4998 & 1.0 \\
\hline C. leucostictus & - & 4.2 & 14.0 & 280.5 & 114.4 & 57.0 & 121.8 & 254.5 & 50.4 & 28.0 & 16.2 & - & 0.1 & 0.1 & 3.0 & 4070 & 0.8 \\
\hline C. bedfordi & - & - & 14.5 & 377.3 & 29.8 & 8.3 & 27.5 & 19.5 & 2.2 & 1.5 & - & - & - & - & 1.0 & 1972 & 0.4 \\
\hline C. zuluensis & 1.0 & 0.8 & 1.5 & 7.8 & 5.6 & 3.7 & 4.0 & 21.0 & 63.0 & 71.8 & 58.0 & 8.5 & 0.5 & 3.9 & 21.0 & 1219 & 0.2 \\
\hline C. subschultzei & - & - & 0.5 & 17.8 & 4.0 & 3.3 & 8.3 & 24.0 & 147.2 & 12.0 & & - & - & 0.1 & - & 1027 & 0.2 \\
\hline C. magnus & 1.0 & 2.8 & 3.5 & 12.3 & 10.8 & 5.7 & 1.0 & 6.0 & 2.2 & 2.0 & 12.2 & 6.8 & 1.4 & 9.8 & 166.0 & 645 & 0.1 \\
\hline C. milnei & - & & - & - & - & 1.5 & 9.8 & 46.5 & 63.8 & 8.8 & 4.8 & - & - & - & - & 612 & 0.1 \\
\hline C. gulbenkiani & - & 0.2 & 0.3 & - & - & 1.0 & 2.5 & 10.5 & 4.8 & 3.0 & 13.0 & 1.7 & 0.4 & - & - & 179 & $<0.05$ \\
\hline C. expectator & - & 0.2 & 0.3 & 25.0 & 5.4 & 1.0 & 3.3 & 5.0 & - & - & - & - & - & - & - & 168 & $<0.05$ \\
\hline C. brucei & - & - & 1.0 & 11.5 & 1.6 & 0.7 & 3.3 & 9.0 & 1.6 & 6.5 & - & - & - & 0.3 & 2.0 & 151 & $<0.05$ \\
\hline C. neavei & - & 0.4 & 0.3 & 17.5 & 1.2 & 1.7 & 2.5 & 6.0 & 1.6 & 2.0 & - & - & - & - & - & 139 & $<0.05$ \\
\hline C. coartatus & - & 0.4 & 1.8 & 9.8 & 3.0 & 1.8 & 1.5 & 9.0 & - & - & - & - & - & 0.9 & 2.0 & 131 & $<0.05$ \\
\hline C. trifasciellus & - & - & 0.5 & 3.0 & 1.4 & 0.2 & - & 6.0 & - & 3.0 & - & - & - & - & - & 58 & $<0.05$ \\
\hline C. sp. \# 54 dark form $\dagger$ & - & - & - & - & - & - & - & - & - & - & 4.4 & 2.3 & 0.1 & 0.4 & - & 43 & $<0.05$ \\
\hline C. tropicalis & - & - & - & 2.0 & 2.4 & 1.3 & 0.5 & - & - & & - & - & - & & - & 30 & $<0.05$ \\
\hline C. glabripennis & - & - & - & - & - & - & 2.0 & - & 2.2 & 2.0 & - & - & - & - & - & 27 & $<0.05$ \\
\hline C. cornutus & - & - & - & - & 0.8 & 2.0 & 1.0 & - & - & - & - & - & - & - & - & 20 & $<0.05$ \\
\hline C. schultzei & - & - & - & 0.8 & - & 0.5 & 0.8 & - & - & - & - & - & - & - & - & 9 & $<0.05$ \\
\hline Nigripennis group & - & - & - & - & - & 0.5 & 0.5 & - & - & - & - & - & - & - & - & 5 & $<0.05$ \\
\hline C. sp. \#107† & - & - & - & - & - & - & - & - & - & - & - & 0.2 & - & - & - & 1 & $<0.05$ \\
\hline Total & 67 & 3081 & 3578 & 29200 & 20400 & 11553 & 11266 & 64968 & 262173 & 54454 & 30043 & 7415 & 1425 & 4246 & 1940 & 505809 & - \\
\hline
\end{tabular}

Note: Bold numbers indicate the winter periods. Species are listed in order of abundance and mean representation is expressed as a percentage (\%) of the total count. C., Culicoides.

$\uparrow$, Culicoides species numbers refer to the numbering system of Meiswinkel, R., 1995, 'Afrotropical Culicoides: Biosystematics of the Imicola group, subgenus Avaritia (Diptera: Ceratopogonidae),

$\dagger$, Culicoides species numbers refer to the numbering system of Meiswinkel, R., 1995, 'Afrotropical Culicoides: Biosystematics
with special reference to the epidemiology of African horse sickness', M.Sc. (Agric.) thesis, University of Pretoria, Pretoria

In the absence of transovarial transmission (Jones \& Foster 1971; Nunamaker et al. 1990), competent Culicoides females only become infected after feeding on a viraemic host. Once infected systemically, a competent female will remain persistently infected, and be able to transmit virus with each subsequent blood meal, until she dies (Mellor et al. 2000). Adult Culicoides females have an average life span of $<20$ days, but depending on the environmental conditions can survive up to 90 days (Mellor et al. 2000). Culicoides imicola adults can survive for more than 15 days and some species, for example Culicoides pycnostictus, up to 54 days at temperatures as low as $-1.5^{\circ} \mathrm{C}$ (Nevill 1971). Adult longevity increases with a decrease in ambient temperature (Gerry \& Mullens 2000; Hunt, Tabachnick \& McKinnon 1989; Lysyk \& Danyk 2007; Wellby et al. 1996). In C. imicola, the number of days from blood feeding to ovipositing and subsequent blood feeding can increase from between 2 and 13 days at $28^{\circ} \mathrm{C}$ to between 19 and 27 days at $20^{\circ} \mathrm{C}$ (Veronesi et al. 2009). Comparable with the results found for AHSV and Culicoides sonorensis (Mellor et al. 1998; Wellby et al. 1996), C. imicola and $C$. bolitinos can harbour bluetongue virus at low levels for more than 20 days at $10{ }^{\circ} \mathrm{C}$ and replicate the virus to transmittable levels when the ambient temperatures increase (Carpenter et al. 2011; Paweska, Venter \& Mellor 2002). It is possible that Culicoides females infected with AHSV can survive throughout winter.

The relatively low virus isolation rates in field-collected Culicoides midges in the present study correspond with previous work done in South Africa (Venter et al. 2006). Even during AHSV outbreaks, the infection prevalence in fieldcollected C. imicola was calculated to be as low as $0.003 \%$ (Venter et al. 2006). In most outbreak situations, however, the superabundance of $C$. imicola will compensate for the relatively low infection prevalence (Venter et al. 2006). Even during outbreak situations the number of viraemic equines with a sufficiently high virus titre in the blood to infect midges in an area will be much less abundant compared with the number of non-viraemic mammals from which midges can take blood. Relatively low infection prevalence in vector species collected in the field is therefore typical of arbovirus infections (Walter, Hildreth \& Beaty 1980). Considering that no virus was detected in any pool $<1000$ midges, it is possible that the numbers of parous females assayed during winter may have been too low for detection with the techniques used. The minimum temperature required for the replication of orbiviruses, including AHSV, in the Culicoides vector was determined to be between $11{ }^{\circ} \mathrm{C}$ and $13{ }^{\circ} \mathrm{C}$ (Carpenter 
et al. 2011). Because of the low winter temperatures, the rate of virus replication and consequently the titre in these potentially infected midges would also have been low (Mellor et al. 1998; Paweska et al. 2002; Wellby et al. 1996).

The number of species found, 27 in summer and 17 in winter, each with a largely unique and mostly unstudied biology and largely unknown vector capacity and competence, will complicate the epidemiology of AHS in the area. Most of the species collected in winter were shown to either bloodfeed on horses (C. imicola, Culicoides magnus, C. nevilli, C. pycnostictus, Culicoides zuluensis, C. bolitinos, Culicoides gulbenkiani and C. enderleini) or to breed in horse dung (C. sp.\# 54 d.f. [dark form] and C. sp.\# 107) (Meiswinkel et al. 2004; Nevill, Nevill \& Venter 2009). Based on the relative abundance countrywide, geographic distribution, virus isolation from field specimens, host preference and larval habitats, Nevill et al. (1992) classified all of these species, except for C. sp.\# 54 d.f. and C. sp.\# 107, as having a high vector potential for the transmission of orbiviruses.

The most abundant Culicoides species in an area will not inevitably be the most competent for a specific virus (Standfast, Dyce \& Muller 1985). Less abundant species should therefore not be excluded from risk assessments. Cumulative laboratory oral susceptibility studies over the last decade indicate at least six of the these, namely C. imicola, C. magnus, C. nevilli, C. zuluensis, C. bolitinos and C. enderleini, to be orally susceptible to infection with AHSV (Paweska, Prinsloo \& Venter 2003; Venter, Graham \& Hamblin 2000; Venter et al. 2006; Venter \& Paweska 2007). Laboratory susceptibility is supported by field isolations of AHSV from C. imicola and C. bolitinos (Meiswinkel \& Paweska 2003; Nevill et al. 1992; Venter et al. 2006). For some of these species, oral susceptibility in the laboratory was significantly higher than that of C. imicola. Culicoides bolitinos, also present throughout the year, is considered to be a potential vector of AHSV (Meiswinkel \& Paweska 2003; Mellor et al. 2000; Paweska et al. 2003; Venter et al. 2000, 2006; Venter \& Paweska 2007). The highest numbers of this species were found from April to June and based on the number of parous females it was the third most abundant species.

In the evaluation of composition and numbers, it should be remembered that light traps do not sample diurnal Culicoides species. These, together with some Culicoides midges with a temporal shift in summer and winter activity (Nathan 1981; Viennet et al. 2012), including C. imicola (Braverman et al. 2003), may play a role in the transmission of AHSV. Mechanical aspiration of horses at Onderstepoort has shown that Culicoides females of different species can be collected from horses before sunset (Scheffer et al. 2012). This phenomenon can become even more pronounced in winter (Braverman et al. 2003; Viennet et al. 2012). Importantly, the attraction range of the light trap may be rather limited and only a relatively small portion of the active, blood-seeking females are intercepted (Venter et al. 2012). The exact size of this portion is not known but it could be $<0.0001 \%$ and is influenced by a great variety of environmental factors. Flight activity and therefore the efficiency of the light traps are suppressed at temperatures below $10^{\circ} \mathrm{C}$ (Mellor et al. 2000). Whilst the first cases of AHSV in South Africa during the study period were only confirmed in November 2010 (AHS Trust 2012), AHSV viral nucleic acid in field collections was detected as early as October 2010 by RTPCR. Although this may indicate over-wintering in adults, these detections may also represent the vaccine strains of AHSV. It has been shown that midges become infected and replicate the attenuated vaccine strains of AHSV (Venter \& Paweska 2007). This early detection of AHSV, which may be field or vaccine, indicates that populations were large enough to become infected and transmit the virus.

The significantly higher number of positive polymerase chain reactions (PCRs) confirms this method to be more sensitive than cell cultures for the detection of AHSV. It should be remembered that whilst virus isolation will detect only viable virus, nucleic acid is detected by PCR. The detection of viral residues by PCR may indicate that at least a primary viraemia had occurred at some point (Quan et al. 2010). The preferred virus detection method used in a study will largely be dictated by the specific objectives of the study.

\section{Conclusion}

The results of this study indicate that, despite a sharp drop in numbers during winter, adult Culicoides midges of several species, including C. imicola, remain present and that bloodfeeding and breeding continues throughout the winter in the Onderstepoort area. The apparent absence of AHSV in the field-collected midges during winter can be ascribed to the relatively low numbers collected, low infection prevalence and low virus titres, all resulting from lower development rates, in the infected midges. The absence of vector-free periods implies that the virus does not need to be introduced from the warmer, frost-free north of the country. It can potentially be present in adult Culicoides midges all year long and outbreaks of AHS can therefore commence as soon as populations reach a critical level.

\section{Acknowledgements Competing interests}

The authors declare that they have no financial or personal relationship(s) which may have inappropriately influenced them in writing this article.

\section{Authors' contributions}

G.J.V. (Agricultural Research Council-Onderstepoort Veterinary Institute) was responsible for the project design. S.N.B.B. (Agricultural Research Council-Onderstepoort Veterinary Institute) was responsible for the collection of the insects. G.J.V., D.M. (Agricultural Research CouncilOnderstepoort Veterinary Institute) \& K.L. (Agricultural Research Council-Onderstepoort Veterinary Institute) did the Culicoides species analyses and age grading of the 
midges. C.L. (University of Pretoria) and K.E. (University of Pretoria) was responsible for the virus isolations. E.H.V. (University of Pretoria) assisted with the virus isolation and the interpretation of results. G.J.V. wrote the manuscript.

\section{References}

African Horse Sickness (AHS) Trust, 2012, African horse sickness, viewed 03 January 2012, from http://www.africanhorsesickness.co.za

Barnard, B.J.H., 1993, 'Circulation of African horse sickness virus in zebra (Equus burchelli) in the Kruger National Park, South Africa, as measured by the prevalence of type specific antibodies', Onderstepoort Journal of Veterinary Research 60 111-117. PMid:8332321

Bosman, P., Brückner, G.K. \& Faul, A., 1995, 'African horse sickness surveillance systems and regionalisation/zoning: The case of South Africa', Revue Scientifique systems and regionalisation/zoning: The case of South Africa', Revue Scientifique
et Technique, Office International des Épizooties 14, 645-653. PMid:8593398

Braverman, Y., Rechtman, S., Frish, A. \& Braverman, R., 2003, 'Dynamics of biting activity of C. imicola Kieffer (Diptera: Ceratopogonidae) during the year', Israeli Journal of Veterinary Medicine 58, 46-56.

Carpenter, S., Wilson, A., Barber, J., Veronesi, E., Mellor, P., Venter, G.J. et al., 2011 'Temperature dependence of the incubation period of orbiviruses in Culicoides biting midges', PloS One 6(11), e27987. http://dx.doi.org/10.1371/journal. pone.0027987, PMid:22125649

Coetzer, J.A.W. \& Guthrie, A.J., 2004, 'African horse sickness', in J.A.W. Coetzer \& R.C. Tustin (eds.), Infectious diseases of livestock, 2nd edn., pp. 1231-1246, Oxford University Press, Cape Town.

Dyce, A.L., 1969, 'The recognition of nulliparous and parous Culicoides (Diptera: Ceratopogonidae) without dissection', Journal of the Australian Entomological Society 8, 11-15. http://dx.doi.org/10.1111/j.1440-6055.1969.tb00727.x

Gerry, A.C. \& Mullens, B.A., 2000, 'Seasonal abundance and survivorship of Culicoides sonorensis (Diptera: Ceratopogonidae) at a southern California dairy, with reference to potential bluetongue virus transmission and persistence', Journal of Medical Entomology 37, 675-688. PMid:11004778

Howell, P.G., 1962, 'The isolation and identification of further antigenic types of African horse sickness virus', Onderstepoort Journal of Veterinary Research 29, 139-149.

Hunt, G.J., Tabachnick, W.J. \& McKinnon, C.N., 1989, 'Environmental factors affecting mortality of adult Culicoides variipennis (Diptera: Ceratopogonidae) in the laboratory', Journal of the American Mosquito Control Association 5, 387-391. laboratory', Journo

Jones, R.H. \& Foster, N.M., 1971, 'Transovarian transmission of bluetongue virus unlikely for Culicoides variipennis', Mosquito News 31, 434-437.

Labuschagne, K., 2007, 'Survey of Culicoides spp. at the National Zoological Gardens of South Africa (Pretoria)', M.Tech. (Veterinary Technology) dissertation, Tshwane University of Technology, Pretoria.

Lysyk, T.J. \& Danyk, T., 2007, 'Effect of temperature on life history parameters of adult Culicoides sonorensis (Diptera: Ceratopogonidae) in relation to geographic origin and vectorial capacity for bluetongue virus', Journal of Medical Entomology 44, 741-751. http://dx.doi.org/10.1603/0022-2585(2007)44[741:EOTOLH]2.0.CO;2, PMid:17915503

MacLachlan, N.J. \& Guthrie, A.J., 2010, 'Re-emergence of bluetongue, African horse sickness, and other orbivirus diseases', Veterinary Research 41, 35. http:// dx.doi.10.1051/vetres/2010007, PMid:20167199

McIntosh, B.M., 1958, 'Immunological types of horse sickness virus and their significance in immunization', Onderstepoort Journal of Veterinary Research 27, 465-538.

Meiswinkel, R., 1995, 'Afrotropical Culicoides: Biosystematics of the Imicola group, subgenus Avaritia (Diptera: Ceratopogonidae), with special reference to the
epidemiology of African horse sickness', M.Sc. (Agric.) thesis, University of epidemiology of
Pretoria, Pretoria.

Meiswinkel, R. \& Paweska, J.T., 2003, 'Evidence for a new field Culicoides vector of African horse sickness in South Africa', Preventive Veterinary Medicine 60, 243253. PMid:12900162

Meiswinkel, R., Venter, G.J. \& Nevill, E.M., 2004, 'Vectors: Culicoides spp.', in J.A.W. Coetzer \& R.C. Tustin (eds.), Infectious Diseases of Livestock, 2nd edn., pp. 93-136, Oxford University Press, Cape Town.

Mellor, P.S., Boorman, J. \& Baylis, M., 2000, 'Culicoides biting midges: Their role as arbovirus vectors', Annual Review of Entomology 45, 307-340. PMid:10761580

Mellor, P.S., Rawlings, P., Baylis, M. \& Wellby, M.P., 1998, 'Effect of temperature on African horse sickness virus infection in Culicoides', Archives of Virology (Supplement) 14, 155-163. PMid:9785504

Nathan, M.B., 1981, 'A study of the diurnal biting and flight activity of Culicoides phlebotomus (Williston) (Diptera: Ceratopogonidae) using three trapping methods', Bulletin of Entomological Research 71, 121-128.

Nevill, E.M., 1971, 'Cattle and Culicoides biting midges as possible overwintering hosts of bluetongue virus', Onderstepoort Journal of Veterinary Research 38, 65-72. PMid:4353606

Nevill, H., Nevill, E.M. \& Venter, G.J., 2009, 'Comparative descriptions of the pupae of a further two Culicoides (Avaritia) species from the dung of large herbivores in South Africa (Diptera: Ceratopogonid
Research 76, 277-284. PMid:21105594
Nevill, E.M., Venter, G.J. \& Edwardes, M., 1992, 'Potential Culicoides vectors of livestock orbivirus', in T.E. Walton \& B.I. Osburn (eds.), Bluetongue, African horse sickness and related orbiviruses. Proceedings of the 2 nd International Symposium, sickness and related orbiviruses. Proceedings of
pp. 306-313, CRC Press, Boca Raton, Florida.

Nunamaker, R.A., Sieburth, P.J., Dean, V.C., Wigington, J.G., Nunamaker, C.E. \& Mecham, J.O., 1990, 'Absence of transovarial transmission of bluetongue virus in Culicoides variipennis: Immunogold labeling of bluetongue virus antigen in developing oocytes from Culicoides variipennis (Coquillett)', Comparative in developing oocytes from Culicoides variipennis (Coquillett)', Comparative
Biochemistry and Physiology 96, 19-31. http://dx.doi.org/10.1016/0300Biochemistry and Physiology
9629(90)90036-R, PMid:1975536

Paweska, J.T., Prinsloo, S. \& Venter, G.J., 2003, 'Oral susceptibility of South African Culicoides species to live-attenuated serotype-specific vaccine strains of African
horse sickness virus (AHSV)', Medical and Veterinary Entomology 15, 436-447. horse sickness viru

Paweska, J.T., Venter, G.J. \& Mellor, P.S., 2002, 'Vector competence of South African Culicoides species for bluetongue virus serotype 1 (BTV-1) with special reference to the effect of temperature on the rate of virus replication in C. imicola and $C$. to the effect of temperature on the rate of virus replication in C. imicola
bolitinos', Medical and Veterinary Entomology 16, 10-21. PMid:11963973

Quan, M., Lourens, C.W., MacLachlan, N.J., Gardner, I.A. \& Guthrie A.J., 2010 'Development and optimisation of a duplex real-time reverse transcription quantitative PCR assay targeting the VP7 and NS2 genes of African horse sickness virus', Journal of Virological Methods 167, 45-52. http://dx.doi.og/10.1016/j. jviromet.2010.03.009, PMid:20304015

Scheffer, E.G., Venter, G.J., Labuschagne, K., Page, P.C., Mullens, B.A., MacLachlan, N.J. et al., 2012, 'Comparison of two trapping methods for Culicoides biting midges and determination of African horse sickness virus prevalence in midge populations at Onderstepoort, South Africa', Veterinary Parasitology 185, 265273. http://dx.doi.org/10.1016/j.vetpar.2011.09.037, PMid:22014560

Standfast, H.A., Dyce, A.L. \& Muller, M.J., 1985, 'Vectors of bluetongue in Australia: Laboratory infections of Culicoides debilipalpis and C. stellifer (Diptera: Ceratopogonidae) with bluetongue virus', in T.L. Barber \& M.M. Jochim (eds.), Progress in clinical and biological research: Bluetongue and related orbiviruses, pp. 177-186, Alan R. Liss, New York. PMid:2989850

Van Ark, H. \& Meiswinkel, R., 1992, 'Subsampling of large light trap catches of Culicoides (Diptera: Ceratopogonidae)', Onderstepoort Journal of Veterinary Research 59, 183-189. PMid:1437020

Venter, G.J., Graham, S.D. \& Hamblin, C., 2000, 'African horse sickness epidemiology: Vector competence of South African Culicoides species for virus serotypes 3, 5 and 8', Medical and Veterinary Entomology 14, 245-250. PMid:11016430

Venter, G.J., Koekemoer, J.J.O. \& Paweska, J.T., 2006, 'Investigations on outbreaks of African horse sickness in the surveillance zone of South Africa', Revue Scientifique et Technique, Office International des Épizooties 25, 1097-1019. PMid:17361773

Venter, G.J., Labuschagne, K., Hermanides, K.G., Boikanyo, S.N.B., Majatladi, D.M. et al., 2009, 'Comparison of the efficiency of five suction light traps under field conditions in South Africa for the collection of Culicoides species', Veterinary Parasitology 166, 299-307. http://dx.doi.org/10.1016/j.vetpar.2009.08.020, PMid:19758757

Venter, G.J., Majatladi, D.M., Labuschagne, K., Boikanyo, S.N.B. \& Morey, L., 2012, 'The attraction range of the Onderstepoort $220 \mathrm{~V}$ light trap for Culicoides biting midges as determined under South African field conditions', Veterinary Parasitology 190, 222-229. http://dx.doi.org/10.1016/j.vetpar.2012.05.019, PMid:22704896

Venter, G.J., Meiswinkel, R., Nevill, E.M. \& Edwardes, M., 1996, 'Culicoides (Diptera: Ceratopogonidae) associated with livestock in the Onderstepoort area, Gauteng, South Africa as determined by light-trap collections', Onderstepoort Journal of Veterinary Research 63, 315-325. PMid:9173363

Venter, G.J., Nevill, E.M. \& Van der Linde, T.C. de K., 1997, 'Seasonal abundance and parity of stock-associated Culicoides species (Diptera: Ceratopogonidae) in different climatic regions in southern Africa in relation to their vector potential', Onderstepoort Journal of Veterinary Research 64, 259-271. PMid:9551477

Venter, G.J. \& Paweska, J.T., 2007, 'Virus recovery rates for wild-type and liveattenuated vaccine strains of African horse sickness virus serotype 7 in orally infected South African Culicoides species', Medical and Veterinary Entomology 21 377-383. PMid:18092976

Veronesi, E., Venter, G.J., Labuschagne, K., Mellor, P.S. \& Carpenter, S., 2009, 'Lifehistory parameters of Culicoides (Avaritia) imicola Kieffer in the laboratory at different rearing temperatures', Veterinary Parasitology 163, 370-373. http:// dx.doi.org/10.1016/j.vetpar.2009.04.031, PMid:19473769

Viennet, E., Garros, C., Rakotoarivony, I., Allène, X., Gardès, L., Lhoir, J. et al., 2012, 'Host-seeking activity of bluetongue virus vectors: Endo/exophagy and circadian rhythm of Culicoides in western Europe', PLoS One 7(10), e48120. http://dx.doi. org/10.1371/journal.pone.0048120

Walker, A.R. \& Boreham, P.F.L., 1976, 'Saline as a collection medium for Culicoides (Diptera, Ceratopogonidae) in blood feeding and other studies', Mosquito News 36, 18-20.

Walter, S.D., Hildreth, S.W. \& Beaty, B.J., 1980, 'Estimation of infection rates in populations of organisms using pools of variable size', American Journal of Epidemiology 112, 124-128. PMid:7395846

Wellby, M.P., Baylis, M., Rawlings, P. \& Mellor, P.S., 1996, 'Effect of temperature on virogenesis of African horse sickness virus in Culicoides variipennis sonorensis (Diptera: Ceratopogonidae) and its significance in relation to the epidemiology of the disease', Bulletin of Entomological Research 86, 715-720. http://dx.doi. org/10.1017/S0007485300039237

Wilson, A., Mellor, P.S., Szmaragd, C. \& Mertens, P.P.C., 2009, 'Adaptive strategies of African horse sickness virus to facilitate vector transmission', Veterinary Research 40, 16. http://dx.doi.org/10.1051/vetres:2008054 